Gut, 1979, 20, 585-589

\title{
Correlation of salivary and gastric acid secretions in duodenal ulcer patients in tropics
}

\author{
P. L. NAGWANI, S. R. NAIK ${ }^{1}$, S. SACHDEV, P. N. SRIVASTAVA, AND \\ H. K. CHUTTANI
}

From the Department of Gastroenterology, Maulana Azad Medical College and Associated Irwin and G.B. Pant Hospitals, New Delhi, India

SUMMARY Salivary flow rates on mechanical stimulation by forced spitting method and by chemical stimulation with $10 \%$ citric acid and gastric acidity using an augmented histamine test were determined in 20 adult patients suffering from duodenal ulcer and in 20 adult control subjects matched with respect to age, sex, and body weight. Salivary flow rates were found to be much higher in response to chemical than to mechanical stimulus in both the groups. Duodenal ulcer patients exhibited an unexplained exaggerated response to chemical stimulation. Salivary pH, amylase, sodium, and potassium levels showed no significant differences between the two groups. The flow rates by either method generally showed a positive correlation with body weight in both the groups. Histamine stimulated gastric acid secretion was higher in duodenal ulcer patients than in controls. Acid secretion did not appear to be related to weight and also showed no consistent correlation with the salivary flow rates. It was concluded that (1) the salivary flow was dependent on body weight in duodenal ulcer patients as well as in controls, and (2) although salivary gland hyperplasia could be postulated in duodenal ulcer patients on the basis of increased salivary flow, the latter was poorly related to maximal acid secretion and therefore, if a combination of parietal cell and salivary gland hyperplasia did exist, it should be considered as incidental.

Patients with duodenal ulcer have been found to have increased salivary secretory rate analogous to gastric acid hypersecretion (Grossman, 1958; Blum and Woodall, 1972). Following the interesting direct relationship between gastric parietal cell mass and maximal acid output in duodenal ulcer patients established by Card and Marks (1960), Blum and Woodall (1972) postulated salivary gland hyperplasia like parietal cell hyperplasia in duodenal ulcer patients (Cox, 1952; Card and Marks, 1960). Normal Indian subjects as well as duodenal ulcer patients show a much lower minimal acid output compared with their Western counterparts, thus suggesting the possibility that Indians might have a lower parietal cell mass (Vakil and Mulekar, 1965; Goyal et al., 1966). No work has been carried out on salivary secretions in Indians, and, although it has been shown that parietal cell mass in healthy Indians is similar to that in Western subjects (Naik et

\footnotetext{
${ }^{1}$ Reprint requests to: Dr S. R. Naik, Gastroenterology Department, St Bartholomew's Hospital, West Smithfield, London EC1A 7BE.
}

Received fcr publication 24 January 1979 al., 1971), no studies have been done on duodenal ulcer patients from India. The present study attempts to determine salivary and gastric acid secretions in duodenal ulcer patients and compare them with healthy individuals from Northern India.

\section{Methods}

Twenty adult control subjects and 20 adults suffering from duodenal ulcer volunteered to undergo the study on an inpatient basis. Preliminary examination of these individuals excluded any abnormality of orodontal, oropharyngeal, and salivary gland areas, and the laboratory data ruled out significant anaemia, presence of parasitic infection on three stool examinations, and abnormalities in serum proteins. The control subjects were drawn from the population attending the surgical outpatients' department for the treatment of minor surgical ailments such as hernia and hydrocoele. Clinical examination and laboratory investigations revealed no gastrointestinal or systemic disease. Duodenal ulcer patients had suggestive clinical symptoms for a period ranging from four months to two years and the diagnosis was 
confirmed by barium meal, which revealed an ulcer crater in the duodenal bulb of 14 patients, deformed duodenal bulb in four, and persistent spastic bulb in two patients. Patients with complicated ulcer disease or very ill patients were not included in the series. The two groups of subjects studied were well matched with respect to sex, age, and body weight (Table 1).

\section{SALIVARY SECRETION STUDIES}

The salivary secretions were obtained by (1) mechanical and (2) chemical stimulation in all 40 individuals.

Table 1 Sex, age, and weight of control subjects and duodenal ulcer patients

\begin{tabular}{|c|c|c|c|}
\hline & $\begin{array}{l}\text { Control } \\
\text { subjects }\end{array}$ & $\begin{array}{l}\text { Duodenal ulcer } \\
\text { patients }\end{array}$ & P value \\
\hline \multicolumn{4}{|l|}{ Sex } \\
\hline Male & 15 & 15 & \\
\hline Female & 5 & 5 & \\
\hline \multicolumn{4}{|l|}{ Age (yr) } \\
\hline Range & $20-49$ & $20-45$ & $>0.05$ \\
\hline Mean & $35 \cdot 9$ & $33 \cdot 6$ & NS \\
\hline SD & $9 \cdot 27$ & $6 \cdot 57$ & \\
\hline \multicolumn{4}{|c|}{ Weight (kg) } \\
\hline Range & $43-60$ & $45-58$ & $>0.05$ \\
\hline Mean & $50 \cdot 45$ & 51.95 & NS \\
\hline SD & 5.04 & $4 \cdot 18$ & \\
\hline
\end{tabular}

NS: not significant.
MECHANICAL STIMULATION METHOD

The method described by Blum and Makhlouf (1971) was followed. After an overnight fast, each subject was asked to exercise the muscles of his cheek and tongue continuously for 10 minutes and squeeze the saliva out into a clean graduated glass test tube through a glass funnel. This volume was measured and expressed as salivary flow per minute (SFR-M). The samples were subjected to determinations of amylase activity by starch iodine method (Wootton, 1964) and of sodium and potassium by flame photometry. A further collection of $15 \mathrm{ml}$ of saliva was then made in a test tube containing liquid paraffin for estimating the $\mathrm{pH}$ of the sample.

\section{CHEMICAL STIMULATION METHOD}

The method used by Blum and Woodall (1972) was followed. After emptying the mouth of all salivary contents, at zero time, $0.3 \mathrm{ml} 10 \%$ citric acid was delivered on the anterior surface of the tongue and the subject painted the buccal mucosa with citric acid by rolling movements of the tongue. At 30 seconds, $5 \mathrm{ml}$ distilled water was delivered rapidly below the tongue by means of a syringe. Between the 45th and 60th seconds, the subject forcefully emptied all the contents of the mouth into a test tube through a funnel. The volume was measured and expressed as salivary flow per minute (SFR-C) after deducting 5.3 $\mathrm{ml}$ out of it.

Table 2 Showing salivary and gastric studies in control subjects and duodenal ulcer patients

\begin{tabular}{|c|c|c|c|c|}
\hline & $\begin{array}{l}\text { Controls } \\
\text { (range/mean/SD) } \\
(20) \dagger\end{array}$ & $\begin{array}{l}\text { Duodenal ulcer } \\
\text { patients } \\
\text { (range/mean/SD) } \\
(20)\end{array}$ & t value & P value \\
\hline $\begin{array}{l}\text { Salivary flow rate } \\
\text { (mechanical-(SFR-M)) } \\
\text { (ml/min) }\end{array}$ & $\begin{array}{l}0 \cdot 26-0 \cdot 64 \\
0 \cdot 45 \\
0 \cdot 12\end{array}$ & $\begin{array}{l}0 \cdot 27-0 \cdot 72 \\
0 \cdot 46 \\
0 \cdot 12\end{array}$ & $0 \cdot 16$ & $>0.05 * \mathrm{NS}$ \\
\hline $\begin{array}{l}\text { Salivary flow rate } \\
\text { (chemical stimulation) } \\
\text { (SFR-C) (ml/min) }\end{array}$ & $\begin{array}{l}1 \cdot 1-5 \cdot 5 \\
2 \cdot 99 \\
1 \cdot 16\end{array}$ & $\begin{array}{l}2 \cdot 9 \cdot 6 \cdot 0 \\
4 \cdot 43 \\
0 \cdot 74\end{array}$ & 4.65 & $<0.001+$ HS \\
\hline Salivary pH & $\begin{array}{l}6 \cdot 5 \cdot 7 \cdot 9 \\
7 \cdot 24 \\
0 \cdot 41\end{array}$ & $\begin{array}{l}6 \cdot 75-7 \cdot 00 \\
7 \cdot 32 \\
0 \cdot 34\end{array}$ & 0.67 & $>0.05 \mathrm{NS}$ \\
\hline $\begin{array}{l}\text { Salivary amylase } \\
\text { (Somogyi units/ml) }\end{array}$ & $\begin{array}{l}417 \cdot 1359 \\
861 \cdot 4 \\
295 \cdot 01\end{array}$ & $\begin{array}{l}300 \cdot 9-1354 \cdot 7 \\
794 \cdot 5 \\
300 \cdot 8\end{array}$ & 0.07 & $>0.05 \mathrm{NS}$ \\
\hline $\begin{array}{l}\text { Salivary sodium } \\
(\mathrm{mmol} / \mathrm{l})\end{array}$ & $\begin{array}{l}6 \cdot 4-32 \cdot 1 \\
16 \cdot 88 \\
7 \cdot 94\end{array}$ & $\begin{array}{l}6 \cdot 0-34 \cdot 8 \\
20 \cdot 68 \\
7 \cdot 49\end{array}$ & 0.05 & $>0.05 \mathrm{NS}$ \\
\hline $\begin{array}{l}\text { Salivary potassium } \\
(\mathrm{mmol} / \mathrm{l})\end{array}$ & $\begin{array}{l}7 \cdot 0-25 \cdot 3 \\
14 \cdot 74 \\
5 \cdot 51\end{array}$ & $\begin{array}{l}10 \cdot 1-40 \cdot 1 \\
18 \cdot 42 \\
7 \cdot 41\end{array}$ & $1 \cdot 79$ & $>0.05$ \\
\hline $\begin{array}{l}\text { Gastric acid } \\
\text { BAO }(\mathrm{mmol} / \mathrm{h})\end{array}$ & $\begin{array}{l}1 \cdot 1 \cdot 6 \cdot 9 \\
3 \cdot 31 \\
1 \cdot 48\end{array}$ & $\begin{array}{l}2 \cdot 0-3 \cdot 1 \\
4 \cdot 63 \\
1 \cdot 68\end{array}$ & & \\
\hline $\mathrm{MAO}(\mathrm{mmol} / \mathrm{h})$ & $\begin{array}{l}9 \cdot 9-18 \cdot 6 \\
13 \cdot 78 \\
2 \cdot 7\end{array}$ & $\begin{array}{l}16 \cdot 5-31 \cdot 8 \\
23 \cdot 32 \\
4 \cdot 6\end{array}$ & $9 \cdot 4$ & $<0.001 \mathrm{HS}$ \\
\hline
\end{tabular}

†Figures in parentheses indicate number of individuals included; NS : not significant; + HS : highly significant. 
GASTRIC ACID SECRETORY STUDIES

The augmented histamine test using a subcutaneous dose of $40 \mu \mathrm{g}$ histamine acid phosphate per $\mathrm{kg}$ body weight was performed in all individuals, following the technique of Kay (1953), and basal and maximal secretions were collected for a period of 0-60 minutes before and after the injection of histamine respectively. The acidity was determined by volumetric titration against $0.1 \mathrm{~N}$ sodium hydroxide to pH 7. The basal and maximal acid outputs (BAO and MAO) were calculated and expressed as mmol per hour.

\section{Results}

The results of the tests for salivary and gastric secretions are summarised in Table 2. It was observed that the mean SFR-C was $2.99 \mathrm{ml} / \mathrm{min}$ compared with SFR-M of $0.45 \mathrm{ml} / \mathrm{min}$ in control subjects, whereas mean SFR-C and SFR-M were 4.43 and $0.46 \mathrm{ml} / \mathrm{min}$ respectively in duodenal ulcer patients. SFR-M and SFR-C showed a significant positive correlation with each other in both groups, but SFR-C was considerably higher than SFR-M in either group. The salivary amylase, sodium, and potassium showed a considerable scatter. Except for SFR-C and MAO, which were both higher in the duodenal ulcer group compared with controls, no other variable showed a significant difference between the groups.

The distributions of different variables in the two groups were observed to be Gaussian, the Figure showing a normal distribution between SFR-C and MAO for each group. Correlation coefficient $r$ was therefore calculated (Table 3). It was observed that in the control group, SFR-M had a significant positive correlation with SFR-C and also with body weight and maximal acid output; SFR-C had no correlation with maximal acid output, but a highly significant correlation with body weight. There was no correlation between maximal acid output and

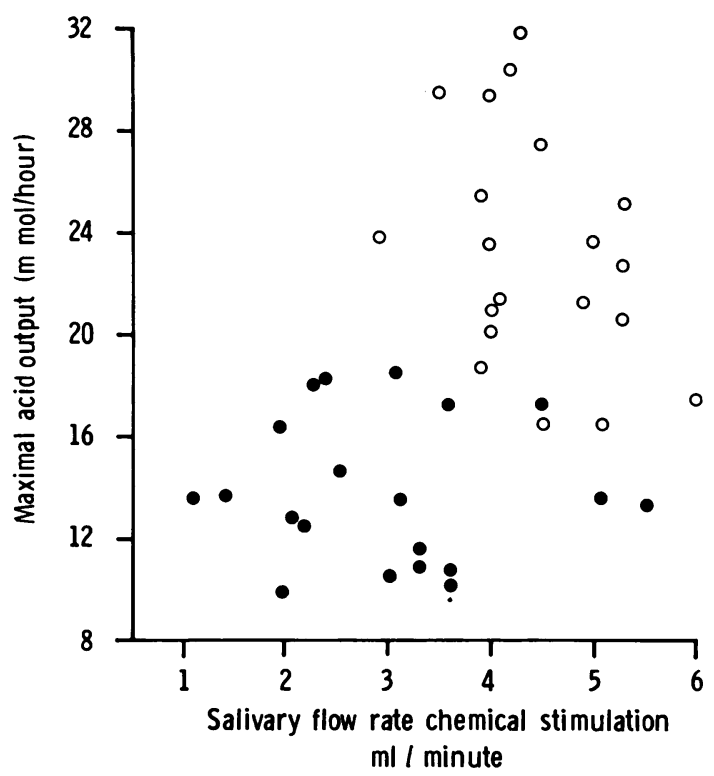

Figure Plot of salivary flow rate on chemical stimulation and maximal acid output in controls and duodenal ulcer patients. Shows a Gaussian distribution. - Normal controls. ODuodenal ulcer patients.

body weight in this group. In the duodenal ulcer group SFR-M had positive correlation with SFR-C, but none with maximal acid output. Further, body weight showed a positive correlation at $10 \%$ level of significance both with SFR-M and with maximal acid output $(r=0.385,0.10<P>0.05)$. SFR-C in this group also correlated poorly with MAO, but had good correlation with body weight.

\section{Discussion}

The results of the present study reveal that there are no significant differences between control subjects and duodenal ulcer patients in the salivary flow rates

Table 3 Correlation coefficients between some variables in control and duodenal ulcer groups

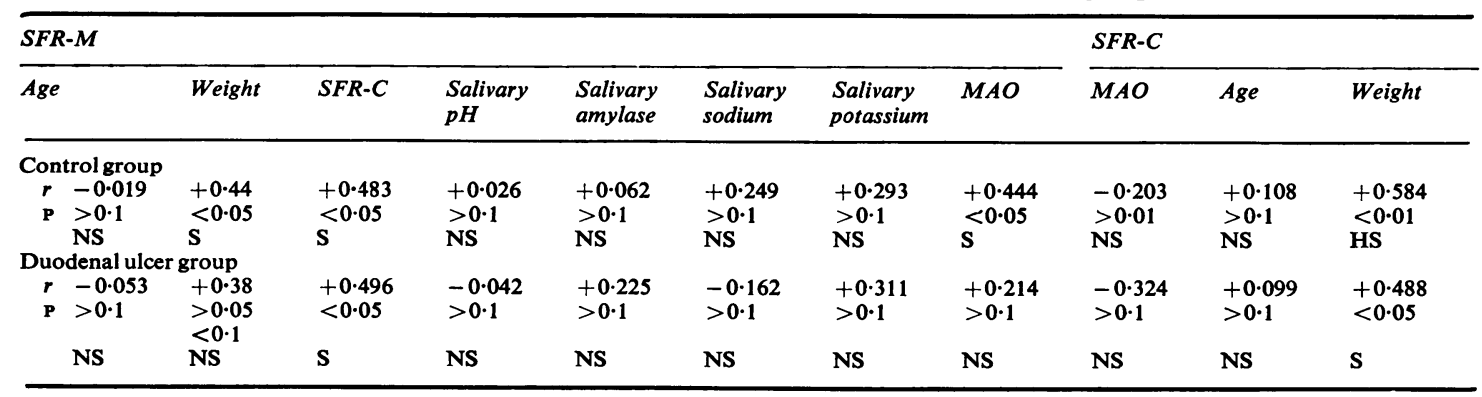

NS : not significant; $S$ : significant; HS : highly significant. 
obtained on mechanical stimulation with forced spitting method. SFR-M in both these groups could be favourably compared with the flow rates reported in Western controls by simple drainage (Spealman, 1943) or by suction (Faber, 1943). However, mean SFR-M of $0.64 \mathrm{ml} / \mathrm{min}$ by the same method in healthy controls of Blum and Makhlouf (1971) are somewhat higher than mean levels of $0.45 \mathrm{ml} / \mathrm{min}$ in our controls, but the differences are not so striking as to label our controls as hyposecretors. What was rather surprising, however, was that, although SFR$M$ in both these groups was identical, SFR-C was six and 10 times higher than SFR-M in controls and duodenal ulcer patients respectively and SFR-C in duodenal ulcer patients was considerably higher than in controls. It therefore appears that the mechanical stimulus is not strong enough to bring out the secretory characteristics, particularly in duodenal ulcer patients who for some reason seem to be exhibiting exaggerated response to the chemical stimulus. Such enhanced response was not observed by Blum and Woodall (1972). It may be pertinent at this stage to enumerate the differences between the above and the present study. The controls in the series of Blum and Woodall were Western white patients suffering from miscellaneous upper gastrointestinal conditions other than duodenal ulcer as opposed to the healthy Indians described in this report. In addition, some of the duodenal ulcer patients in the Western study had important abnormalities in the gut apart from their ulcer. Further, the white individuals in their study were older and weighed more than our North Indians. These differences in age and body weight could perhaps explain some of the differences in the results of the two studies, but it should be remembered that oriental duodenal ulcer patients are generally younger and weigh less than their Western counterparts (Baron, 1964; Goyal et al., 1966; Cheng et al., 1977). Although the numbers of subjects and patients studied by us are too small to warrant a firm inference, we observed that both methods produced a similar salivary flow rate in a large number of healthy subjects, and in otherwise healthy tobacco chewers studied concurrently as parts of other studies (unpublished data). With our present limited understanding of salivary gland physiology, we are unable to provide an explanation for a high secretory rate-unmasked only by citric acid stimulation-in our duodenal ulcer patients.

Age had no influence in either group on salivary flow by either method. This finding contrasts with the findings of Blum and Makhlouf (1971) of agedependent increase of the salivary flow in controls. Once again, their study also cannot be compared with ours, as they included individuals of varying age groups, ranging from 4 to 35 years. The controls studied by Blum and Woodall (1972) on the other hand showed a declining trend of salivary flow with age, but no such relationship was observed in their duodenal ulcer patients. It therefore appears that in an adult population the relationship between age and salivary flow is not constant. The salivary flow in the present study generally showed a significant positive relationship with body weight, except that SFR-M in the duodenal ulcer group correlated with body weight at the $10 \%$ level of significance. These findings of significant positive correlations between these two variables are in general agreement with the findings of Blum and Makhlouf in their control subjects and of Blum and Woodall in their 'controls' and duodenal ulcer patients. The salivary $\mathrm{pH}$, sodium, potassium, and amylase activity in normal subjects and duodenal ulcer patients were similar and thus no important pathophysiological implications can be ascribed to them.

The duodenal ulcer patients were found to have higher maximal acid output than the normal subjects. This is a universally acknowledged finding (Baron, 1963; Vakil and Mulekar, 1965; Lawrie and Forrest, 1965; Goyal et al., 1966; Desai et al., 1970) and is considered to be due to hyperplasia of gastric parietal cells observed in these patients (Cox, 1952; Card and Marks, 1960). As in the studies of Baron (1963) and of Lawrie and Forrest (1965), but unlike in those of Blum and Woodall (1972), we observed no correlations between body weight and maximal acid output. Blum and Woodall also observed weightrelated salivary flow rates and documented a direct relation between maximal acid output and salivary flow rate. We could not demonstrate consistent correlations between maximal acid output and salivary flow rate, but our duodenal ulcer patients had an exaggerated response of salivary flow to chemical stimuli, and so a salivary gland hyperplasia postulated by Blum and Woodall may be operative in our patients too. We have, however, some reservations in accepting the above workers' analogy of increases in parietal cell mass and salivary glass mass, as, unlike their study, ours did not show a consistent relationship between maximal acid output and salivary flow rate. Are both these secretions and the respective cell masses really body weight dependent? Body weight was found to influence salivary flow rate in normal children and young adults (Blum and Makhlouf, 1971), in duodenal ulcer patients and 'control' patients (Blum and Woodall, 1972), as well as in the present study of normal subjects and duodenal ulcer patients. However, the positive correlation observed between body weight and maximal acid output in normal Western subjects and duodenal ulcer patients (Baron, 1964; Baron, 1969; Blum and Makhlouf, 
1971 ; Blum and Woodall, 1972; Hobsley et al., 1975) was not confirmed in some of the Indian studies (Vakil and Mulekar, 1965; Goyal et al., 1966; Naik et al., 1974). The discrepancy appears to arise from the fact that most of the latter studies were performed on individuals with a narrow range of low body weights and low lean body mass. The latter factor seems to be the more important determinant of maximal acid output (Baron, 1969; Hobsley et al., 1975). The difficulty in obtaining heavier Indian duodenal ulcer patients, already referred to, arises perhaps from the geographical and ethnic differences in the distributions of body weights and builds of the Oriental and Western subjects.

However, the observation that salivary flow rate was correlated with the body weight tempts us to suggest that it might be more dependent on body weight and build than maximal acid output, although any firm conclusions on the issue should await more studies from other centres. Further examination of distributions of maximal acid output and SFR-C (Fig.) reveals that maximal acid output levels were above the upper limits in normal subjects in 17 out of 20 duodenal ulcer patients and were below the lower limits of duodenal ulcer patients in 15 out of 20 normal subjects; on the other hand, only one out of 20 duodenal ulcer patients had SFR-C above the upper limit of normal subjects and nine out of 20 normal subjects had values below the lowest value in the duodenal ulcer group. Higher maximal acid output values therefore tend to discriminate between normal subjects and duodenal ulcer patients more than SFR-C levels. The postulates of salivary gland hyperplasia on the basis of salivary flow therefore need direct confirmation by histological methods, as has been done in the case of parietal cells (Cox, 1952; Card and Marks, 1960; Cheng et al., 1977). The existence of a combination of hyperplasia of salivary gland and parietal cells in duodenal ulcer patients should be considered as coincidental in the present state of our knowledge.

The authors wish gratefully to acknowledge the help received in revising the manuscript from Mrs Jane Wadsworth of the Statistics Department of St Bartholomew's Hospital.

\section{References}

Baron, J. H. (1963). Studies of basal and peak acid output with an augmented histamine test. Gut, 4, 136-144.

Baron, J. H. (1964). Peptic ulcer, gastric secretion and body build. Gut, 5, 83-85.

Baron, J. H. (1969). Lean body mass, gastric acid and peptic ulcer. Gut, 10, 637-642.

Blum, A. L., and Makhlouf, G. M. (1971). Determinants of salivary response to mechanical stimulation. Gut, 12, 650653.

Blum, A. L., and Woodall, J. W. (1972). Salivary secretion in duodenal ulcer disease. Gut, 13, 713-717.

Card, W. I., and Marks, I. N. (1960). The relationship between the acid output of the stomach following "maximal" histamine stimulation and the parietal cell mass. Clinical Science, 19, 147-163.

Cheng, F. C. Y., Lam, S. K., and Ong, G. B. (1977). Maximum acid output to graded doses of pentagastrin and its relations to parietal cell mass in Chinese patients with duodenal ulcer. Gut, 18, 827-832.

Cox, A. J., Jr (1952). Stomach size and its relation to chronic peptic ulcer. Archives of Pathology, 54, 407-422.

Desai, H. G., Zaveri, M. P., Mohalla, D. J., and Antia, F. P. (1970). Acid output in control subjects and patients with duodenal ulcer using fixed doses of histamine. Indian Journal of Medical Research, 58, 33-38.

Faber, M. (1943). The causes of xerostomia. Acta Medica Scandinavica, 113, 69.

Goyal, R. K., Gupta, P. S., and Chuttani, H. K. (1966). Gastric acid secretion in Indians with particular reference to the ratio of basal to maximal acid output. Gut, 7, 619623.

Grossman, M. I. (1958). Inhibition of gastric and salivary secretion by darbid. Gastroenterology, 35, 312-315.

Hobsley, M., Whitfield, P. F., Faber, R. G., and Parkin, J. V. (1975). Hypersecretion and length of history in duodenal ulceration. Lancet, 2, 101-104.

Kay, A. W. (1953). Effect of large doses of histamine on gastric secretion of $\mathrm{HCl}$ : an augmented histamine test. British Medical Journal, 2, 77-80.

Lawrie, T. H., and Forrest, A. M. P. (1965). The measurement of gastric acid. Postgraduate Medical Journal, 41, 408-417.

Naik, S. R., Bajaj, S. C., Goyal, R. K., and Chuttani, H. K. (1974). Dose-response relationship of graded doses of intravenous histamine infusion on gastric acid secretion in man. Digestion, 11, 321-332.

Naik, S. R., Bajaj, S. C., Goyal, R. K., Gupta, D. N., and Chuttani, H. K. (1971). Parietal cell mass in healthy human stomach. Gastroenterology, 61, 682-685.

Spealman, C. R. (1943). The volume flow of resting salivary secretion. American Journal of Physiology, 139, 225-229.

Vakil, B. J., and Mulekar, A. M. (1965). Studies with maximal histamine test. Gut, 6, 364-371.

Wootton, I. D. P. (1964). Micro-Analysis in Medical Biochemistry, 4th edn, p. 106. Churchill: London. 